\title{
Biopersistence of fibrous thermal insulations (AES fibers) after heat exposure using intratracheal instillation technique
}

\section{(Biopersistência de isolantes térmicos fibrosos (fibras AES) após exposição ao calor utilizando técnica de instilação intratraqueal)}

\author{
D. G. M.Silva ${ }^{1 *}$, A. R. Ridgley ${ }^{2}$,W. L. Vasconcelos ${ }^{3}$ \\ ${ }^{1}$ Vallourec Soluções Tubulares do Brasil S.A., Av. Olinto Meireles 65, 30640-010, Belo Horizonte, MG, Brazil \\ ${ }^{2}$ Vallourec Star, LP, 2669 Martin Luther King Jr. Blvd, Youngstown, Ohio 44510, USA \\ ${ }^{3}$ Universidade Federal de Minas Gerais, Departamento de Engenharia Metalúrgica e de Materiais, Laboratório \\ de Materiais Cerâmicos, Belo Horizonte, MG, Brazil
}

\begin{abstract}
Because refractory ceramic fibers (RCF) were classified as possibly pathogenic to humans, alkaline earth silicate (AES) wools have been used as a substitute product for high-temperature applications. All in vivo assays developed to evaluate its pathogenicity were assessed using as-received AES samples. The classification as a pathogen does not apply if the retention half-time for fibers longer than $20 \mu \mathrm{m}$ is less than 40 days. Therefore, this work describes the evaluation of one AES sample after heat treatment, using the intratracheal instillation technique in rats. Over a three-month post-treatment period, the rats were dissected, and their lungs were examined. The half-time calculation for the retained fibers longer than $20 \mu \mathrm{m}$ in the lungs was 56 days. Therefore, this AES sample after heat treatment could be presumed to have pathogenic potential for humans.
\end{abstract}

Keywords: alkaline earth silicate fibers, biopersistence, biosoluble fibers, cristobalite, crystalline silica, man-made vitreous fibers.

\section{Resumo}

Pelo fato das fibras cerâmicas refratárias (FCR) serem classificadas como agentes possivelmente patogênicos à espécie humana, as fibras de silicato de metais alcalino-terrosos (AES) podem ser utilizadas como potenciais substitutos. Os experimentos in vivo que avaliaram a patogenicidade das fibras AES utilizaram esse produto in natura. A classificação como agente patogênico não se aplica, caso o tempo de retenção de meia-vida das fibras de comprimento superior a 20 um for inferior a 40 dias. Sendo assim, este trabalho teve como objetivo avaliar o risco ocupacional de uma amostra de fibra AES após exposição a altas temperaturas, através da técnica de instilação intratraqueal em ratos. Durante o período de três meses, as cobaias foram dissecadas e seus pulmões foram examinados. O tempo de meia-vida calculado para as fibras retidas nos pulmões e com comprimento superior a $20 \mu \mathrm{m}$ foi de 56 dias. Desta forma, pôde-se avaliar o grau de patogenicidade da amostra estudada.

Palavras-chave: fibras de silicato de metais alcalino-terrosos, biopersistência, fibras biossolúveis, cristobalita, sílica cristalina, fibras vítreas feitas pelo homem.

\section{INTRODUCTION}

Refractory materials are highly useful for hightemperature insulation applications in a great variety of industries, especially in metallurgical environments, such as steel plants. Because of energy costs, environmental concerns and with the dangers associated with the use of asbestos, manmade vitreous fibers (MMVF) such as refractory ceramic fibers (RCF) and alkaline earth silicate (AES) wools have been used. Reasons for their employment are directly linked to their low density, low thermal conductivity, low shrinkage, high resilience and high thermal shock resistance $[1,2]$. These characteristics allow their use as wear linings in

*dgmsilva@yahoo.com.br

(D) https://orcid.org/0000-0001-7012-4293 a great variety of equipment such as tempering and reheating furnaces and steel ladle covers. However, surely because of their fibrous form, which they share with the asbestos minerals, these manmade materials also showed concern regarding possible health effects.

As a consequence, a number of experimental researches were performed regarding health concerns and based on animal studies. RCF has been deemed to be a possible pathogen by reputable regulatory bodies, including the US Environmental Protection Agency, the European Chemical Agency and the International Agency for Research on Cancer. The concern raised by the aforementioned institutions is that there is inadequate evidence in humans for the pathogenicity of RCF, but there is sufficient evidence in experimental animals for its pathogenicity. In contrast, considering AES (identification X-607) materials, there is inadequate 
evidence in experimental animals for its pathogenicity [3]. Furthermore, no significant pathological evidence has been demonstrated by different exposure routes during tests conducted on AES wools [4-6]. All research was developed considering the assessment of AES products as-received in other words, without being installed or exposed to heat. However, similar to RCF, AES exposed to temperature over time generate microstructure and morphology changes that could contribute negatively to health concerns, especially among workers involved in the removal of these materials from equipment such as high-temperature furnaces. It is well known that RCF and AES products can recrystallize in some crystalline phases, depending on temperature and time, and one of these mineralogical phases may be cristobalite, a polymorph of crystalline silica [7-9]. This recrystallization route is concerning because there is sufficient evidence in experimental animals and humans for the pathogenicity of inhaled cristobalite [10]. Furthermore, in reference to mineral wools, crystallinity is highly important concerning health because at least one crystalline category of fiber, silicon carbide whiskers, shows biological effects in animals (cytotoxicity) and humans (fibrosis) [11].

In this context, this article addresses the estimation of the biopersistence of one AES sample after temperature and time exposure. This study aims to directly overcome the lack of results regarding the assessment of AES wools using in vivo method after the recrystallization process and cristobalite phase development. In addition, it is a great contribution to the in vitro short-term assays that evaluated the intrinsic toxicity of 4 types of heated AES products [12]. The authors alleged that cristobalite content has minor or no relevance on the pathogenicity of the heated AES with rat alveolar macrophages. For this reason, the researchers suggested in vivo experiments to verify their conclusions.

\section{EXPERIMENTAL PROCEDURE}

This study, a health and environmental safety assessment, followed the current standard operating procedures and the principles of Good Laboratory Practice from German Chemicals Law [13], under the regulations of the German Animal Protection Law [14] and in accordance with the guideline 'Biopersistence of fibers: intratracheal instillation' [15] and German regulations for mineral fibers [16].

Fiber sample choice: the AES product evaluated was supplied in blanket form, flexible, free of binders and with nominal dimensions of $7620 \times 610 \times 13 \mathrm{~mm}$ (Supermag 1200 , Ibar/Nutec). It is a high-temperature spun soluble wool with random orientation made from a blend of calcia, silica and magnesia. Supermag 1200 belongs to the same class of AES (identification X-607) material that is exonerated from being classified as possibly pathogenic to humans. Table I shows general information of the sample according to the technical datasheet. Chemical analysis: the sample was heat treated at $550{ }^{\circ} \mathrm{C}$ for $30 \mathrm{~min}$ to calculate its loss on ignition (LOI), which was less than $0.1 \%$. To determine each oxide, a Variant Vista-Pro was used for inductively coupled plasma optical emission spectrometry (ICP-OES) observations.

Heat treatment: the sample was heat treated at $1050{ }^{\circ} \mathrm{C}$ for $120 \mathrm{~h}$. The temperature and time targets were chosen based on prior research in which both recrystallization process and cristobalite development were detected [9]. In addition, the target temperature chosen is the maximum continuous operating temperature recommended by the supplier and the maximum achievable temperature of the hardening furnace in which this type of material is typically installed. The blanket sample was arranged in a $217 \mathrm{~kW}$, $440 \mathrm{~V}, 60 \mathrm{~Hz}$, Combustol electric furnace. The furnace was equipped with K-type thermocouples, ceramic wool insulation, and resistance heating elements throughout to ensure homogenous heating. These heating rates were adopted from a European standard: $10{ }^{\circ} \mathrm{C} / \mathrm{min}$ from room temperature up to $50{ }^{\circ} \mathrm{C}$ below the test temperature and $2{ }^{\circ} \mathrm{C} / \mathrm{min}$ for the last $50{ }^{\circ} \mathrm{C}$ [17]. The sample was cooled inside the furnace to room temperature without controlled cooling rates.

$X R D$ : following heat treatment at $1050{ }^{\circ} \mathrm{C}$ for $120 \mathrm{~h}$, the phase development assessment was performed at room temperature by XRD (X-ray diffraction), which was performed in a Philips PANalytical X'Pert PRO diffractometer, using $\mathrm{CuK} \alpha$ radiation. XRD patterns were taken in the $2 \theta$ angle range from $6^{\circ}$ to $100^{\circ}$, using a scan step size of $0.017^{\circ}$ and a scan step time of $19.68 \mathrm{~s}$. The generator voltage and tube current were $40 \mathrm{kVA}$ and $40 \mathrm{~mA}$, respectively. A sample of this material was prepared by crushing it in a ceramic mortar and pestle. The crystalline phases were identified using the standard database PDF-2 Release 2010 from ICDD (International Center for Diffraction Data) and X'Pert HighScore v. 2011 software. FTIR spectroscopy: samples were prepared as pellets with $\mathrm{KBr}$ and examined in a Perkin-Elmer Spectrum 1000 spectrometer. FTIR (Fouriertransform infrared) spectra were taken in the spectral range from 1400 to $400 \mathrm{~cm}^{-1}$, with a resolution of $4 \mathrm{~cm}^{-1}$ and 128 scans. One sample of this material was prepared by crushing it in a ceramic mortar and pestle. A small quantity of the product $(\sim 1 \mathrm{mg})$ was mixed with $\mathrm{KBr}(\sim 100 \mathrm{mg})$. One tablet was made using a pastillator and a manual hydraulic press (9000 $\mathrm{kgf}$ for $3 \mathrm{~min}$ ). The $\mathrm{KBr}$ was previously dried in an

Table I - General information of the tested fiber.

[Tabela I - Informações gerais da fibra testada.]

\begin{tabular}{|c|c|c|c|c|c|c|c|}
\hline \multirow{2}{*}{ Type } & \multicolumn{4}{|c|}{ Chemical composition (\%) } & \multirow{2}{*}{$\begin{array}{l}\text { Thickness } \\
\text { (mm) }\end{array}$} & \multirow{2}{*}{$\begin{array}{l}\text { Bulk density } \\
\left(\mathrm{kg} / \mathrm{m}^{3}\right)\end{array}$} & \multirow{2}{*}{$\begin{array}{l}\text { Classification } \\
\text { temperature }\left({ }^{\circ} \mathrm{C}\right)\end{array}$} \\
\hline & $\mathrm{SiO}_{2}$ & $\mathrm{CaO}+\mathrm{MgO}$ & $\mathrm{Al}_{2} \mathrm{O}_{3}+\mathrm{ZrO}_{2}+\mathrm{TiO}_{2}$ & Other oxides & & & \\
\hline AES & $60-70$ & $25-40$ & $<6$ & $<1$ & 25 & 128 & 1200 \\
\hline
\end{tabular}


electric muffle furnace at $200{ }^{\circ} \mathrm{C}$ for $12 \mathrm{~h}$. SEM/EDS: to evaluate the heat-treated material, test pieces were prepared for SEM (scanning electron microscopy) tests by embedding them in an epoxy resin, followed by grinding and polishing them with a diamond paste of $1 \mu \mathrm{m}$ in grain size, and coating them with gold (30 $\mathrm{nm}$ thick film). SEM was performed in a Jeol JSM-6360 LV microscope operated at $15 \mathrm{kV}$ with typical beam sizes in the range $30-100 \mathrm{~nm}$ and 1000x magnification. Compositional analyses were performed using a Noran EDS (energy dispersive spectroscopy) system coupled in the scanning electron microscope.

Sizing of the bulk material: the size distribution of the instilled fibers should be similar to that used for inhalation biopersistence studies, if technically feasible, according to the European Union protocol [15]: a mean aspect ratio between its length (L) and its diameter (D) of at least $\mathrm{L} / \mathrm{D} \geq 3$, with the former greater than $5 \mu \mathrm{m}$ and the latter less than $3 \mu \mathrm{m}$; a rat respirable fiber diameter is preferred (diameter as close as possible to $0.8 \mu \mathrm{m}$ ) with an upper limit in any case of $3 \mu \mathrm{m}$ ( $95 \%$ less than $3 \mu \mathrm{m}$ ); at least a $20 \%$ of the WHO fibers ( $\mathrm{L}>5 \mu \mathrm{m}, \mathrm{D}<3 \mu \mathrm{m}$ and $\mathrm{L} / \mathrm{D} \geq 3$ ) in suspension should have a length $\mathrm{L}>20 \mu \mathrm{m}$ and, for this length fraction, a geometric mean diameter (GMD) as close as possible to $0.8 \mu \mathrm{m}$, if technically feasible. The diameters could be smaller than $0.8 \mu \mathrm{m}$ if justified by the dimensions of the bulk wool. According to the German standard [18], the GMD of the WHO fiber fraction should be close to $0.6 \mu \mathrm{m}$ (value rounded to 1 decimal digit) but not below this value.

Characterization of the fiber and particle fractions: the material fractions were characterized by a scanning electron microscope, Supra 55, Carl Zeiss NTS, using secondary electrons for imaging. It was operated at $25 \mathrm{kV}$ with typical beam sizes in the range $30-100 \mathrm{~nm}$ and magnification of at least 2000x. Approximately $1-5 \mathrm{mg}$ of the fractions were suspended in 20-50 mL of filtered water. The suspension was then sonicated (Sonorex RK 510H, Bandelin) at $35 \mathrm{kHz}$ and $160 \mathrm{~W}$ until it appeared to be uniform (approximately $60 \mathrm{~s}$ ). The suspensions were then filtered through Nuclepore filters $(25 \mathrm{~mm}$ in diameter, pore size $0.2 \mu \mathrm{m})$. The filters were then mounted on Al stubs and coated with gold (30 nm thick film). All objects observed at 2000x magnification were counted. During the sizing process, an object was considered to be a fiber if the mean aspect ratio of length to diameter was at least 3:1. All other objects were considered as particles. No truncation in the measurements was accepted. Diameters of fibers observed at 2000x magnification were measured at full-screen magnification. No lower or upper limits were imposed on length or diameter. The length and diameter were recorded individually for each fiber measured. Sufficient fields of view were evaluated such that at least a total of $0.15 \mathrm{~mm}^{2}$ of the filter surface was examined. The following rules were used for counting: i) fibers: a size-selected analysis using a minimum of 100 fibers for both categories ( $\mathrm{L} \leq 5 \mu \mathrm{m}$ and $\mathrm{L}>20 \mu \mathrm{m}$ ) and a minimum of 200 fibers for the category $5<\mathrm{L} \leq 20 \mu \mathrm{m}$. The distance between two fields of view for analysis was at least 10 fields. Sizing was halted when $1 \mathrm{~mm}^{2}$ of the filter surface was examined, even if the minimum number of fibers had not been reached for a category. The total number of fibers per filter was determined by normalizing the surface area counted to the total surface area of the filter; ii) particles: the recording was halted when the total number of particles counted reached 100.

Animals, acclimation, housing and maintenance: 48 female Wistar rats were used. The age of the animals at the beginning of treatment was approximately 9 weeks, and their weights were approximately 207.7-265.5 g. Female Wistar rats have been previously used in various fiber biopersistence studies at Fraunhofer Institute. In most cases, biopersistence studies have been conducted with one sex only because no sex-specific effects are known for this type of study. The animals were acclimated to the lab environment for approximately two weeks. Upon arrival, all animals were thoroughly examined, which included the skin, coat, eyes, ears, nose and bodily orifices. To be accepted for the study, the physical conditions of the animals were observed daily during the acclimation period. Animals were housed in polycarbonate cages and were maintained under conventional laboratory conditions. Drinking water and a regular diet were offered ad libitum during the entire study. The temperature and relative humidity of the laboratory were monitored electronically and recorded on a continuous basis. The limits were set to $22 \pm 2{ }^{\circ} \mathrm{C}$ for temperature and $55 \% \pm 15 \%$ for relative humidity. An automated timing device controlled the lighting to provide $12 \mathrm{~h}$ light/dark.

Defining of the animal groups, instillation procedure, sterility testing, suspension monitoring and sacrifice dates: two groups were considered for this research. The first group identified as the 'study group' was treated with the fiber/particle fractions already mentioned. The daily dose per rat was $0.5 \mathrm{mg}$ suspended in $0.3 \mathrm{~mL}$ of sterile isotonic saline $(\mathrm{NaCl}$ in distilled water, $\mathrm{pH} \sim 7)$, during 4 consecutive days, for a total of $2 \mathrm{mg}$ per rat. The second group identified as the 'negative control group' was treated only with sterile isotonic saline solution, $0.3 \mathrm{~mL}$ per day and per rat during 4 consecutive days. During the instillation process, all females were anaesthetized daily by $\mathrm{CO}_{2} / \mathrm{O}_{2}$, and their tracheas were exposed to instill the suspension. Immediately prior to the daily administration, a $1 \mathrm{~mL}$ sample of the fiber suspension was taken and sterilized for testing. The sample was inoculated into thioglycollate broth, appropriate for supporting growth of all major rat pathogens (aerobic, microaerophile, anaerobic). Testing was performed in duplicate using Staphylococcus aureus as a positive control. Two additional quality controls were used during the instillation process; concentration monitoring and counting/dimension of the fractions. The fiber concentration was monitored on each treatment day by taking one $0.3 \mathrm{~mL}$ aliquot of the suspension prior to starting and one after completing the intratracheal instillation. These aliquots were passed through Nuclepore filters (diameter $25 \mathrm{~mm}$ ) and used for gravimetric determination of the test concentration. The counting/dimension of the fractions used the same methodology mentioned, but the aliquots 
were taken only prior to the start of the instillation. The counting/dimension of the fractions was equal to the process described previously. To evaluate the fraction clearance process retained in the target tissue, 5 rats from each group and from each instillation date were dissected at 4 distinct predefined dates over a 3-month period. The lungs were dehydrated by freeze drying (Christ, Beta 1-8) and subjected to low-temperature ashing (200-G, Plasma Technics). Both procedures were validated in previous studies regarding hot thermal insulation wools (HTIW), showing no changes into the fiber dimensions [19]. The fraction of the ashed lung was suspended in filtered water and evaluated using all techniques already described by disaggregation, filtration and fraction analysis defined previously. The numbers of animals per group and the dissection dates are reported in Table II. Only 5 lungs from the study group of each dissection date were analyzed through SEM. The two remaining were reserved for further optional analysis, if necessary.

Half-time calculations for the retained fibers in the lungs:

Table II - Number of animals per group and sacrifice dates. [Tabela II - Número de animais por grupo e por data de sacrifício.]

\begin{tabular}{cccccc}
\hline Group & $\begin{array}{c}2 \\
\text { days }\end{array}$ & $\begin{array}{c}14 \\
\text { days }\end{array}$ & $\begin{array}{c}32 \\
\text { days }\end{array}$ & $\begin{array}{c}88 \\
\text { days }\end{array}$ & Sum \\
\hline $\begin{array}{c}\text { Study group } \\
\text { Negative control } \\
\text { group }\end{array}$ & 5 & 5 & 5 & 5 & 20 \\
\hline
\end{tabular}

to determine the number of fibers ( $\mathrm{L}>20 \mu \mathrm{m})$ remaining in the target tissue at the completion of the intratracheal instillation, a nonlinear regression technique was used. Halftime calculations were performed on the other fractions as well. The following criteria were adopted to evaluate the results. If the regression explains at least $80 \%$ of the data variance, a single exponential model should be used:

$$
\% \text { of fibers remained }=a \cdot e^{(- \text {b.time })}
$$

where $\mathrm{a}$ and $\mathrm{b}$ are the coefficients of the exponential model used, according to the guideline 'Biopersistence of fibers: intratracheal instillation' [15]. Otherwise, a double exponential model should be used to explain the data, according to:

$$
\% \text { of fibers remained }=a_{1} \cdot e^{\left(-b_{1}+\text { time }\right)}+a_{2} \cdot e^{\left(-b_{2} \text { time }\right)}
$$

According to the results explained by the single exponential model, the half-time should be calculated by:

$$
\mathrm{T}_{1 / 2}=\frac{\ln 2}{\mathrm{~b}}
$$

As for the data explained by the double exponential model, two half-times should be calculated using:

$$
\begin{aligned}
& \mathrm{T}_{\frac{1}{2}-1}=\frac{\ln 2}{\mathrm{~b}_{1}} \\
& \mathrm{~T}_{\frac{1}{2}-2}=\frac{\ln 2}{\mathrm{~b}_{2}}
\end{aligned}
$$

The half-times listed in Eqs. D and E often represent the faster and slower clearance phases, respectively. To show just one index, including both half-times $\left(\mathrm{T}_{\frac{1}{2}-1}, \mathrm{~T}_{\frac{1}{2}-2}\right)$ it should be obtained using:

$$
\mathrm{W}-\mathrm{T}_{1 / 2}=\left(\frac{\mathrm{a}_{1}}{\mathrm{a}_{1}+\mathrm{a}_{2}}\right) \cdot \mathrm{T}_{\frac{1}{2}-1}+\left(\frac{\mathrm{a}_{2}}{\mathrm{a}_{1}+\mathrm{a}_{2}}\right) \cdot \mathrm{T}_{\frac{1}{2}-2}
$$

The entire methodology described followed the European protocol, which evaluates the biopersistence of wools using the intratracheal instillation method [15]. Specific use of the fraction $\mathrm{L}>20 \mu \mathrm{m}$ to explain the clearance process is judged by another research [20]. In these experiments, the researchers considered that fibers longer than $20 \mu \mathrm{m}$ were more potentially pathogenic compared with shorter ones. Regarding a product with a classification temperature between 1000 and $1200^{\circ} \mathrm{C}$, German regulations permit their use if the half-time for WHO fibers in the biopersistence test is $<65$ days [16].

\section{RESULTS}

Chemical analysis: the chemical composition of the bulk material is listed in Table III without the LOI value. The results were in agreement with the fiber datasheet and the European standard used to develop this work [17]. XRD: the XRD pattern of the sample after the heat treatment is shown in Fig. 1. Supermag devitrified into wollastonite 1A $(\beta)$, pseudowollastonite $(\mu)$, wollastonite $2 \mathrm{M}(\alpha)$, and cristobalite $(\theta)$. Formation of wollastonite was already identified at temperatures of approximately $1000{ }^{\circ} \mathrm{C}$ and after $24 \mathrm{~h}$. Cristobalite phase was also identified but at $1050{ }^{\circ} \mathrm{C}$ and after $24 \mathrm{~h}$ [21]. FTIR spectroscopy: as shown in Fig. 2 the FTIR spectrum confirmed the results obtained from the XRD pattern. The broad band at approximately $1000 \mathrm{~cm}^{-1}$ is mainly attributed to the silicate IR absorption of wollastonite [22]. The Si-O-Si symmetric stretching vibration absorption peak of silicon oxygen tetrahedron structure in wollastonite is near the band at $681 \mathrm{~cm}^{-1}$ [23]. The bands at approximately 796 and $473 \mathrm{~cm}^{-1}$ were attributed to the $\mathrm{Si}-\mathrm{O}$ symmetry stretching vibration and bending vibration due to the presence of the cristobalite [24]. Broad bands above $1400 \mathrm{~cm}^{-1}$ were not present because no absorption peaks were found. SEM/EDS: these analyzes were used to evaluate the presence of elements that could help to identify other phases than those detected by XRD. The element magnesium was detected (Fig. 3). Considering a typical product with similar chemical characteristics after heating at $1000{ }^{\circ} \mathrm{C}$ and $24 \mathrm{~h}$, diopside $\left[\mathrm{CaMg}\left(\mathrm{SiO}_{3}\right)_{2}\right]$ was identified but in small concentrations [21]. This phase was also observed between 800 and $900{ }^{\circ} \mathrm{C}$ and after $72 \mathrm{~h}$ of heating [9]. 
Table III - Chemical composition (wt\%) after ignition of the sample.

[Tabela III - Composição química (\% em massa) após ensaio de perda ao fogo.]

\begin{tabular}{cccccccccc}
\hline $\mathrm{SiO}_{2}$ & $\mathrm{CaO}$ & $\mathrm{MgO}$ & $\mathrm{SO}_{3}$ & $\mathrm{Al}_{2} \mathrm{O}_{3}$ & $\mathrm{Fe}_{2} \mathrm{O}_{3}$ & $\mathrm{Na}_{2} \mathrm{O}$ & $\mathrm{TiO}_{2}$ & $\mathrm{~K}_{2} \mathrm{O}$ & Others* \\
\hline $65.9 \pm 0.3$ & $27.8 \pm 0.1$ & $5.50 \pm 0.11$ & $0.21 \pm 0.02$ & $0.19 \pm 0.01$ & $0.10 \pm 0.01$ & $0.04 \pm 0.01$ & $0.02 \pm 0.01$ & $0.02 \pm 0.01$ & trace \\
\hline *- $\mathrm{SrO}, \mathrm{ZrO}, \mathrm{MnO}, \mathrm{P}_{2} \mathrm{O}_{5}, \mathrm{BaO}$. & & & & & & & & &
\end{tabular}

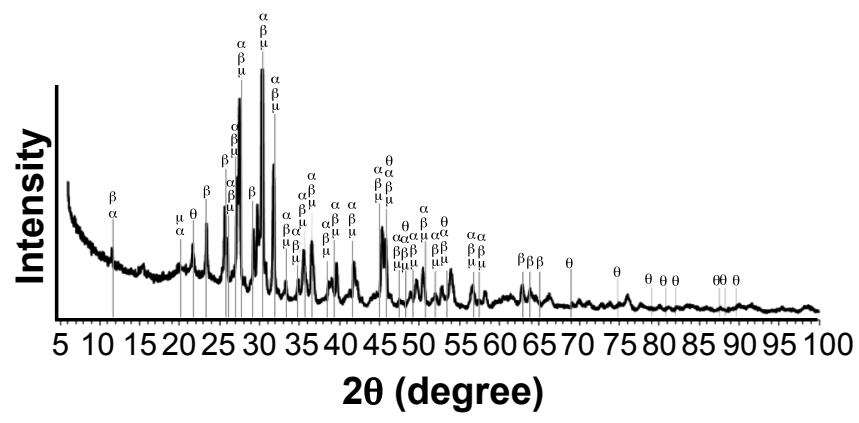

Figure 1: XRD pattern of Supermag sample after heat treatment. PDF 2 ICCD: 084-0654 - wollastonite $1 \mathrm{~A}\left(\mathrm{CaSiO}_{3}\right)$ - $\beta$; 074-0874 - pseudowollastonite $\left[\mathrm{Ca}_{3}\left(\mathrm{Si}_{3} \mathrm{O}_{9}\right)\right]-\mu ; 084-0655$ - wollastonite $2 \mathrm{M}$ $\left(\mathrm{CaSiO}_{3}\right)-\alpha ; 082-0512$ - cristobalite $\left(\mathrm{SiO}_{2}\right)-\theta$.

[Figura 1: Difratograma de raios $X$ da amostra de fibra Supermag após tratamento térmico.]

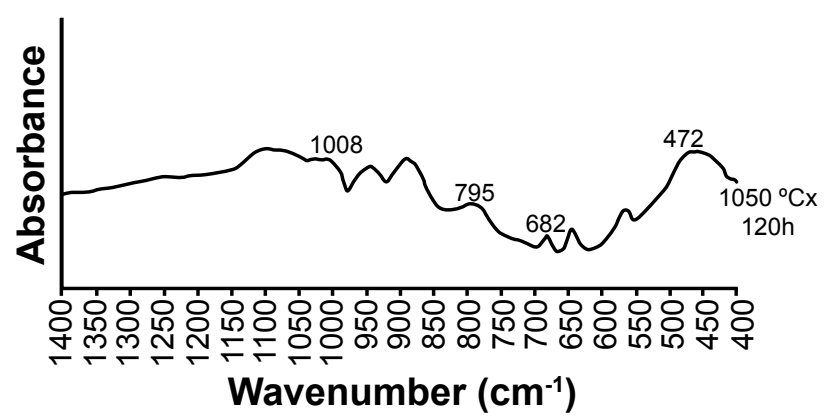

Figure 2: FTIR spectrum of Supermag fiber sample after heat treatment.

[Figura 2: Espectro de FTIR da amostra de fibra Supermag após tratamento térmico.]
Sizing of the bulk material: the results shown in Table IV were used to validate one of the basic assumptions described in the European protocol [15]. It demonstrates that at least $20 \%$ of the WHO fibers were longer than $20 \mu \mathrm{m}$, and the mean percentage was equal to $18.76 \%$. These results do not disqualify the study because such variations are accepted by the protocol. Characterization of the fiber fractions and particles: the results were used to verify the fulfillment of the basic assumptions regarding fractions used during the four consecutive days of the instillation process. First, all fibers maintained the mean aspect ratio ( $\mathrm{L} / \mathrm{D} \geq 3 \mu \mathrm{m})$. Second, $50 \%$ of fibers longer than $20 \mu \mathrm{m}$ had a GMD (geometric mean diameter) value equal to $0.72 \mu \mathrm{m}$, and $95 \%$ of this fraction resulted in a GMD value $\leq 1.70 \mu \mathrm{m}$. The GMD values and the mean length of the fractions were evaluated at a $95 \%$ confidence level. The GMD of the fraction $\mathrm{L}>20 \mu \mathrm{m}$ was $0.72 \pm 0.32 \mu \mathrm{m}$, and the mean length of the WHO fibers was $14.06 \pm 1.20 \mu \mathrm{m}$. The concentration of each aliquot (fiber+saline) taken before and after the instillation process is shown in Table $\mathrm{V}$. These values adhere to the protocol requirement $(0.5 \mathrm{mg} / 0.3 \mathrm{~mL}$ per day $)$. Regarding sterility results, no turbidity of the culture medium occurred.

Half-time calculations for the retained fibers in the lungs: the results of the fibers retained in the lungs are presented in Table VI. According to the European Commission Directive 97/69/EC, the classification as a pathogen need not apply if a short-term biopersistence test by intratracheal has shown that fibers longer than $20 \mu \mathrm{m}$ have an overall retention halftime less than 40 days [25]. The results demonstrated that the value was 56 days, and for the WHO fraction, it was 299 days $\left(R^{2}=0.95\right)$. The mean number of particles $\left(10^{6} / 1\right.$ ung $)$ were plotted versus each sacrifice dates. The retention
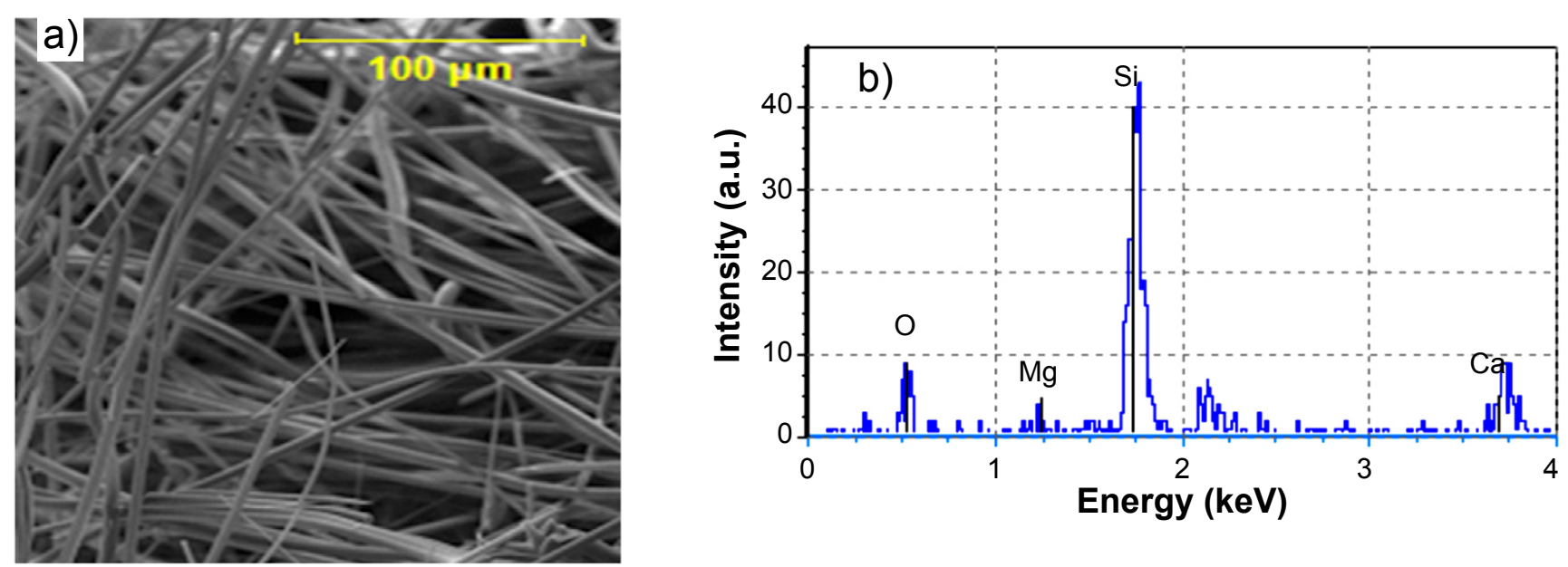

Figure 3: SEM micrography (a) and EDS spectrum (b) of Supermag fiber sample after heat treatment.

[Figura 3: Micrografia de MEV e espectro de EDS da amostra de fibra Supermag após tratamento térmico.] 
Table IV - Fiber concentration in suspension.

[Tabela IV - Concentração das fibras em suspensão.]

\begin{tabular}{cccccc}
\hline Parameter & Day 0 & Day 1 & Day 2 & Day 3 & Mean \\
\hline $\mathrm{N}^{\circ}$ of fibers counted & 414 & 411 & 411 & 410 & 412 \\
All fibers $\left(10^{6} / 1.2 \mathrm{~mL}\right)$ & 64.8 & 55.2 & 57.0 & 60.6 & 59.4 \\
WHO fibers $\left(10^{6} / 1.2 \mathrm{~mL}\right)$ & 36.3 & 32.9 & 37.4 & 42.1 & 37.2 \\
Fibers $(\mathrm{L}<5 \mu \mathrm{m})\left(10^{6} / 1.2 \mathrm{~mL}\right)$ & 28.5 & 22.3 & 19.6 & 18.5 & 22.2 \\
Fibers $(5<\mathrm{L}<20 \mu \mathrm{m})\left(10^{6} / 1.2 \mathrm{~mL}\right)$ & 29.6 & 27.4 & 29.8 & 33.9 & 30.2 \\
Fibers $(\mathrm{L}>20 \mu \mathrm{m})\left(10^{6} / 1.2 \mathrm{~mL}\right)$ & 6.65 & 5.47 & 7.61 & 8.20 & 6.98 \\
Total length of the fibers $(\mathrm{m} / 1.2 \mathrm{~mL})$ & 602.4 & 523.5 & 599.1 & 652.7 & 594.4 \\
$\mathrm{~N}^{\circ}$ of particles counted & 108 & 107 & 141 & 106 & 116 \\
$\mathrm{Particles}\left(10^{6} / 1.2 \mathrm{~mL}\right)$ & 263.2 & 259.4 & 341.4 & 257.0 & 280.2 \\
\hline
\end{tabular}

Table V - Gravimetric concentration in fiber suspension (mg/0.3 mL).

[Tabela V - Concentração gravimétrica das fibras em suspensão $(\mathrm{mg} / 0.3 \mathrm{~mL})$.

\begin{tabular}{cccccc}
\hline \multicolumn{5}{c}{ Day of the instillation } \\
& 1 & 2 & 3 & 4 & Mean \\
\hline Beginning & 0.49 & 0.50 & 0.51 & 0.51 & 0.50 \\
Ending & 0.44 & 0.48 & 0.48 & 0.47 & 0.47 \\
Mean & 0.47 & 0.49 & 0.50 & 0.49 & 0.49 \\
\hline
\end{tabular}

half-time of fractions $\mathrm{L}>20 \mu \mathrm{m}$ and WHO was calculated by a nonlinear regression using the Gauss-Newton method of iteration. A single exponential fitted the data because the regression explained $92 \%$ of the variance $\left(\mathrm{R}^{2}=0.92\right)$.

\section{DISCUSSION}

The Supermag 1200 sample was heat-treated according to the methodology previously described, which resulted in the formation of wollastonite 1A, pseudowollastonite,

Table VI - Analyses of the fibers in the lung ash of individual animals.

[Tabela VI - Análises das fibras retidas nos pulmões por animal.]

\begin{tabular}{|c|c|c|c|c|c|c|c|c|c|c|c|}
\hline \multirow{2}{*}{$\begin{array}{c}\text { Sacrifice } \\
\text { date }\end{array}$} & \multirow{2}{*}{$\begin{array}{l}\text { Animal } \\
\text { Id. }\end{array}$} & \multirow{2}{*}{$\begin{array}{l}\mathrm{N}^{\circ} \text { of } \\
\text { fibers } \\
\text { counted }\end{array}$} & \multicolumn{5}{|c|}{ Number of fibers $\left(10^{6} /\right.$ lung $)$} & \multirow{2}{*}{$\begin{array}{l}\text { Calculated } \\
\text { mass of } \\
\text { fibers }(\mu \mathrm{g})\end{array}$} & \multirow{2}{*}{$\begin{array}{l}\text { Length } \\
\text { of fibers } \\
(\mu \mathrm{m})\end{array}$} & \multirow{2}{*}{$\begin{array}{c}\text { Particles } \\
\text { counted }\end{array}$} & \multirow{2}{*}{$\begin{array}{c}\mathrm{N}^{\circ} \text { of } \\
\text { particles } \\
\left(10^{6} / \mathrm{lung}\right)\end{array}$} \\
\hline & & & $\begin{array}{c}\text { All } \\
\text { fibers }\end{array}$ & $\begin{array}{l}\text { WHO } \\
\text { fibers }\end{array}$ & $\begin{array}{l}\mathrm{L} \leq 5 \\
\mu \mathrm{m}\end{array}$ & $\begin{array}{c}5<\mathrm{L} \leq 20 \\
\mu \mathrm{m}\end{array}$ & $\begin{array}{c}\mathrm{L}>20 \\
\mu \mathrm{m}\end{array}$ & & & & \\
\hline \multirow{5}{*}{2 days } & 5001 & 404 & 54.5 & 31.4 & 23.2 & 26.3 & 5.104 & 751 & 497 & 106 & 231.0 \\
\hline & 5002 & 402 & 31.2 & 17.9 & 13.3 & 15.7 & 2.236 & 496 & 261 & 113 & 89.4 \\
\hline & 5003 & 412 & 63.9 & 35.0 & 28.9 & 30.1 & 4.895 & 940 & 550 & 103 & 193.3 \\
\hline & 5004 & 405 & 33.5 & 17.3 & 16.2 & 15.5 & 1.807 & 364 & 261 & 111 & 103.6 \\
\hline & 5005 & 407 & 55.2 & 34.0 & 21.2 & 30.3 & 3.699 & 761 & 479 & 102 & 149.1 \\
\hline \multirow{5}{*}{14 days } & 5008 & 415 & 42.3 & 28.4 & 13.9 & 26.4 & 1.951 & 578 & 352 & 117 & 54.5 \\
\hline & 5009 & 405 & 39.8 & 21.5 & 18.3 & 19.6 & 1.904 & 462 & 294 & 101 & 95.1 \\
\hline & 5010 & 408 & 37.4 & 19.9 & 17.5 & 18.1 & 1.836 & 485 & 288 & 105 & 71.9 \\
\hline & 5011 & 408 & 57.5 & 31.8 & 25.7 & 29.2 & 2.626 & 660 & 431 & 101 & 91.7 \\
\hline & 5012 & 403 & 54.9 & 31.8 & 23.1 & 28.9 & 2.893 & 783 & 430 & 103 & 75.9 \\
\hline \multirow{5}{*}{32 days } & 5015 & 401 & 39.9 & 21.7 & 18.2 & 20.5 & 1.244 & 392 & 276 & 102 & 36.4 \\
\hline & 5016 & 407 & 52.6 & 29.9 & 22.7 & 27.9 & 2.026 & 587 & 395 & 108 & 74.2 \\
\hline & 5018 & 383 & 22.3 & 12.4 & 9.9 & 11.5 & 0.958 & 252 & 162 & 101 & 38.4 \\
\hline & 5019 & 404 & 43.9 & 25.1 & 18.8 & 23.2 & 1.953 & 622 & 343 & 102 & 90.8 \\
\hline & 5020 & 405 & 35.4 & 21.7 & 13.7 & 20.3 & 1.475 & 496 & 272 & 110 & 70.0 \\
\hline \multirow{5}{*}{88 days } & 5022 & 380 & 35.3 & 15.6 & 19.7 & 14.9 & 0.687 & 311 & 212 & 103 & 54.9 \\
\hline & 5023 & 408 & 48.1 & 22.9 & 25.2 & 21.6 & 1.229 & 617 & 309 & 141 & 106.2 \\
\hline & 5024 & 368 & 49.9 & 20.1 & 29.8 & 19.5 & 0.545 & 498 & 279 & 114 & 68.0 \\
\hline & 5025 & 402 & 49.5 & 24.4 & 25.1 & 23.3 & 1.143 & 513 & 321 & 102 & 56.6 \\
\hline & 5026 & 408 & 59.4 & 26.8 & 32.6 & 25.5 & 1.296 & 501 & 366 & 101 & 71.8 \\
\hline
\end{tabular}


wollastonite $2 \mathrm{M}$, diopside and cristobalite. The three phases identified were previously observed in other researches $[9$, 21]. Owing to the chemical composition of the sample ( $\mathrm{Si}$, $\mathrm{Ca}$ and $\mathrm{Mg}$ ), it was expected to find these crystalline phases after the recrystallization, which is a process dependent on both time and temperature [26]. It is important to emphasize that after installation, this product typically remains in service for a long period of time near its suggested operating temperature. Thus, the concentration of cristobalite and other crystalline phases at the hot face lining will be higher compared with the exposure used in this study. Therefore, the concern for potential health effects of these species during a maintenance outage must be discussed because both cristobalite and the degree of crystallinity in mineral wools could be considered pathogenic to humans $[10,11]$.

For the resulting stock material, the GMD for the WHO fiber fraction was $0.64 \mu \mathrm{m}$. The GMD for fibers longer than $20 \mu \mathrm{m}$ in length was $0.72 \mu \mathrm{m}$. The result for $\mathrm{L}>20 \mu \mathrm{m}$ was slightly below the value of $0.8 \mu \mathrm{m}$, which is preferred to the European protocol [15]. According to the German standard [18] the GMD for the WHO fibers should be close to 0.6 $\mu \mathrm{m}$ but not below this value for wool biopersistence studies. After the completion of the instillation process, the rats were dissected and examined at 4 predetermined intervals within 88 days of post-treatment. The fibers retained in lungs were analyzed using nonlinear regression techniques.

The biopersistence of the Supermag 1200 was calculated through the retention half-time of this sample in the lung in an in vivo assay. According to the European regulation [25], the classification as a pathogen does not apply if the retention half-time for wools longer than $20 \mu \mathrm{m}$ is less than 40 days. The corresponding value for this fraction was 56 days for the sample of Supermag 1200. An in vitro study concluded that cristobalite content appears minor or of no relevance to the intrinsic toxicity of heat-treated AES wools in short-term assays with rat alveolar macrophages [12]. Whereas in vitro experiments measure only dissolution rates of the fibers, those in vivo measure the overall retention behavior of the material in the lung, which include dissolution and clearance rates [3]. This fact explains in part the difference between the results. It is also suitable to evaluate other parameters, which are summarized by the shorthand expression '3D's', for dose-dimension-durability [7]. The classification temperature of the Supermag 1200 sample is $1200{ }^{\circ} \mathrm{C}$. According to German regulations, the use of these materials is allowed in Germany if the half-time for WHO fibers in the biopersistence test is $<65$ days [16]. For this study, the result was 299 days.

\section{CONCLUSIONS}

The main purpose of this experiment was to calculate the retention half-time of a heat-treated AES wool after the completion of the intratracheal instillation assay. Cristobalite and other phases were identified. The calculated half-time of the Supermag samples longer than $20 \mu \mathrm{m}$ was greater than 40 days. For the WHO fibers, the corresponding value was greater than 65 days. Therefore, the Supermag sample after exposure to heat could be presumed to have pathogenic potential for humans. However, other in vivo research would be interesting to confront the result. The results presented in this study demonstrate an important issue about the health and occupational aspects of using AES wools after exposure to heat. It is important to determine the actual temperature at which AES materials can be exposed. As an example, depending on the operational conditions of the equipment, AES wools installed as a wear lining in hardening furnaces can have a lifetime greater than 10 years. Therefore, before the installation process, it is important to use thermogravimetric analyses combined with phase identification methodologies to define a safe material temperature limit because of the recrystallization process.

\section{ACKNOWLEDGMENTS}

The authors thank Dr. Roman Halter and his team from Fraunhofer Institute for Toxicology and Experimental Medicine for their help with the experiments and discussions. The authors are also grateful to the VALLOUREC group for the financial support and for the institutions CNPq, CAPESPROEX and FAPEMIG. The authors thank IBAR/NUTEC for the sample donation.

\section{REFERENCES}

[1] D.G.M. Silva, W.L. Vasconcelos, Cerâmica 63, 367 (2017) 281.

[2] D.G.M. Silva, W.L. Vasconcelos, Cerâmica 64, 369 (2018) 30.

[3] IARC, "Man-made vitreous fibres", IARC Monographs on the Evaluation of Carcinogenic Risks to Humans 81 (2002) 238.

[4] B. Bellmann, H.A. Schaeffer, H. Muhle, Ann. Occup. Hyg. 46 (2002) 166.

[5] R.C. Brown, B. Bellmann, H. Muhle, H. Ernst, G. Pohlmann, P. Sébastien, Ann. Occup. Hyg. 46 (2002) 102.

[6] T.W. Hesterberg, G.A. Hart, J. Chevalier, W.C. Miller, R.D. Hamilton, J. Bauer, P. Thevenaz, Toxicol. Appl. Pharmacol. 153 (1998) 68.

[7] R.C. Brown, P.T.C. Harrison, Regul. Toxicol. Pharmacol. 64 (2012) 296.

[8] P. Comodi, F. Cera, G.D. Gatta, N. Rotiroti, P. Garofani, Ann. Occup. Hyg. 54 (2010) 893.

[9] A.F Gualtieri, E. Foresti, I.G. Lesci, N. Roveri, M.L. Gulatieri, M. Dondi, M. Zapparoli, J. Hazard. Mater. 162 (2009) 1494.

[10] IARC, "Silica, some silicate, coal dust and paraaramid fibrils", IARC Monographs on the Evaluation of Carcinogenic Risks to Humans 68 (1997) 42.

[11] IARC, Mechanisms of fibre carcinogenesis, IARC Press, Lyon (1996).

[12] C. Ziemann, P.T.C. Harrison, B. Bellmann, R.C. Brown, B.K. Zoitos, P. Class, Inhal. Toxicol. 26 (2014) 113.

[13] Chemikaliengesetz [German Chemicals Law], §19a, 
Appendix 1 (2013).

[14] Tierschutzgesetz [German Animal Protection Law] (2006).

[15] European Commission, Guideline ECB/TM/27 rev. 7 , "Biopersistence of fibres - intratracheal instillation" (1998).

[16] Gefahrstoffverordnung [Hazardous Substances Ordinance] (2010).

[17] Eur. Stand., prEN 1094-1, "Insulating refractory products - terminology, classification and methods of test for high temperature insulation wool products", Eur. Comm. Standard., Brussels (2008) 1.

[18] Technische Regeln für Gefahrstoffe [Technical Rules for Hazardous Substances] TRGS 905 (2014).

[19] B. Bellmann, H.A. Schaeffer, H. Muhle, Inhal. Toxicol. 22 (2010) 817.

[20] D.M. Bernstein, K. Donaldson, U. Decker, S. Gaering,
P. Kunzendorf, J. Chevalier, S.E. Holm, Inhal. Toxicol. 20 (2008) 1009.

[21] Th. Tonnesen, R. Telle, in: $46^{\text {th }}$ Int. Colloq. Refractor., Aachen (2003) 149.

[22] M.A. Encinas-Romero, J. Peralta-Haley, J.L. Valenzuela-García, F.F. Castillón-Barraza, J. Biomater. Nanobiotechnol. 4 (2013) 327.

[23] Z. Sun, Z. Bai, H. Shen, S. Zheng, R.L. Frost, Mater. Res. Bull. 48 (2013) 1013.

[24] I.A. Rahman, P. Vejayakumaran, C.S. Sipaut, J. Ismail, M. Abu Bakar, R. Adnan, C.K. Chee, Colloids Surf. A Physicochem. Eng. Asp. 294 (2007) 102.

[25] Eur. Comm. Directive 97/69/EC (1997) 19.

[26] T.P. Brown, P.T.C. Harrison, Regul. Toxicol. Pharmacol. 68 (2014) 152.

(Rec. 28/02/2018, Rev. 23/04/2018, 01/07/2018, Ac. $18 / 08 / 2018)$ 